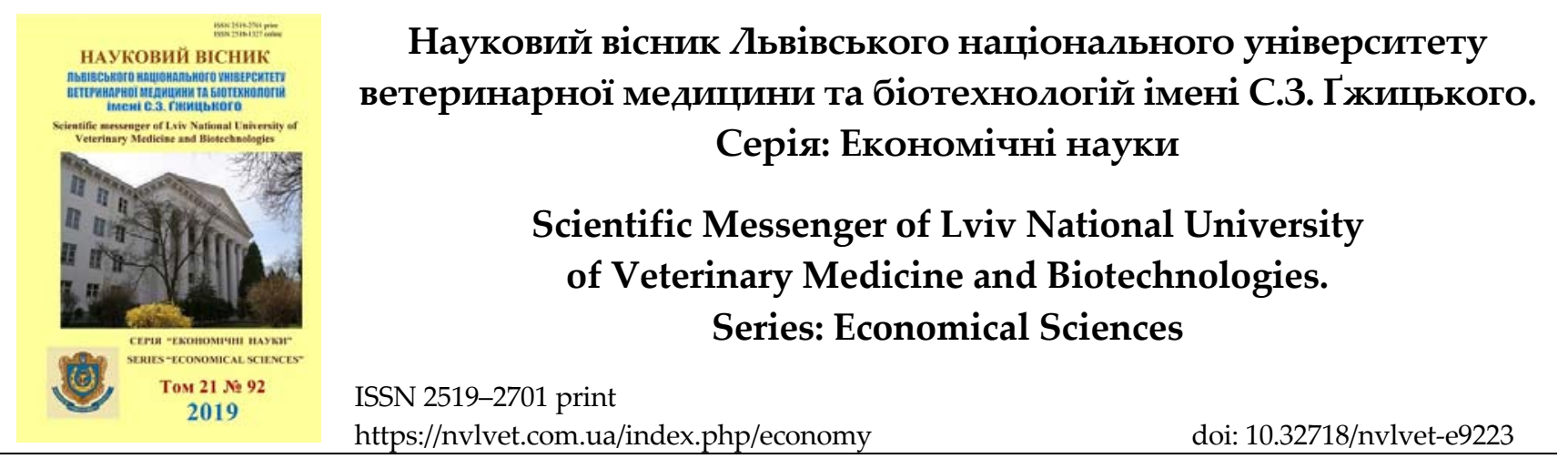

UDC 341. 339. 3:330

\title{
Legislative regulatory aspects of the veterinary pharmacy market in the European Union
}

\author{
H.D. Harvas
}

State Scientific-Research Control Institute of Veterinary Medicinal Products and Feed Additives, Lviv, Ukraine

Article info

Received 11.02.2019

Received in revised form 14.03.2019

Accepted 15.03.2019

State Scientific-Research Control Institute of Veterinary Medicinal Products and Feed Additives

11, Donetska str., Lviv,

79019, Ukraine.

Tel.: +38-097-188-71-55

E-mail:garvac@ukr.ua
Harvas, H.D. (2019). Legislative regulatory aspects of the veterinary pharmacy market in the European Union. Scientific Messenger of Lviv National University of Veterinary Medicine and Biotechnologies. Series: Economical Sciences, 21(92), 137-140. doi: 10.32718/nvlvet-e9223

Production of veterinary pharmacy plays an important role both in animal care and public health, such as for food safety or animal origin to prevent the spread of diseases transmitted to humans through animals. The European market for Animal Health develops rapidly filled with innovative products, updated regulatory system at the legislative level, in order to protect human health, animals and the environment. Today, the focus of attention in the European Union (EU) on the pharmaceutical industry - Is the improvement of the legal framework and its adaptation to the needs and characteristics of the veterinary pharmaceutical industry in particular. Thus Ukraine today - is an intensive process of harmonization, implementation and, at the same time, improvement of the regulatory system, in which international regulatory documents are the basis for the creation of the veterinary pharmaceutical legislation of Ukraine, according to EU requirements.

Key words: legislative aspects, veterinary pharmacy, EU requirements.

\section{Законодавчі регуляторні аспекти ринку продукції ветеринарної фармації Європейського Союзу}

\author{
Г.Д. Гарвас
}

Державний науково-дослідний контрольний інститут ветеринарних препаратів та кормових добавок, м. Львів, Украӥна

\begin{abstract}
Продукиія ветеринарної фармації відіграє важливу роль, як у догляді за тваринами так і охороні здоров'я людей, наприклад, для забезпечення безпечності харчових продуктів тваринного походження чи для запобігання поширенню захворювань, що передаються людині через тварин. Свропейський ринок охорони здоров'я тварин, розвивається швидкими темпами, наповнюється інновачійною продукиією, оновлюється нормативно-правова система на законодавчому рівні, з метою забезпечення захисту здоров'я людей, тварин та навколишнього середовища. Сьогодні, акиент уваги у Свропейському Союзі (СС) щодо галузі фармації- ие удосконалення нормативно-правової бази та ї̈ адаптачія до потреб і особливостей галузі ветеринарної фармачії зокрема. Відтак сьогодення України - че інтенсивний прочес гармонізаџії, імплементаиії та водночас удосконалення нормативно-правової системи, в якій міжнародні нормативні документи є підгрунтям у створенні ветеринарного фармацевтичного законодавства Украйни, відповідно до вимог ЄC.
\end{abstract}

Ключові слова: законодавчі аспекти, ветеринарна фармація, вимоги ЄС.

Вступ

Продукція, яка поставляється на ринки ЄС в обов'язковому порядку повинна відповідати усім іiі вимогам, спрямованим на забезпечення захисту спо- живачів, в тому числі це стосується і продукції галузі ветеринарної фармації. Загальні вимоги у сфері безпеки продукції визначені Директивою Європейського Парламенту та Ради 2001/95/СС від 03.12.2001 p. “Про загальну безпеку продукції”. Відповідно до 
положень Директиви, продукт вважається безпечним, якщо відповідає положенням безпеки, передбаченим в європейському законодавстві або, у разі відсутності таких правил, за умови відповідності національним вимогам держави-члена ЄС де він продається, або вводиться у ринковий обіг.

В минулому році СС в значній мірі оновив своє ветеринарне законодавство, для України, яка обрала шлях євроінтеграції, надзвичайно важливим є вдосконалити і гармонізувати своє нормативно-правове законодавство у галузі ветеринарної фармації. Сьогодні перший крок зроблено - це робота над проектом нового Закону України "Про ветеринарну медицину". Цей законопроект визначатиме правові та організаційні засади здійснення діяльності у сферах забезпечення захисту здоров'я та благополуччя тварин, ветеринарної практики, виробництва та обігу ветеринарних препаратів, побічних продуктів тваринного походження.

Різні аспекти фармацевтичного ринку СС досліджувались в роботах таких вчених: Косенка Ю.М., Коцюмбаса І.Я., Величка В.О., Яновича Д.В., Музики В.П., Бушуєвої І.Б., та інших (Bushuieva, 2013; Velychko et al., 2014; Kosenko, 2014; Harvas \& Muzyka, 2017; Bushueva et al., 2017). Поряд $з$ тим, питання щодо системи нормативно-правового та законодавчого аспектів у сфері фармації, зокрема ветеринарної фармації у СС не досліджувалися.

Мета роботи - вивчити нормативно-правове регулювання та законодавчі аспекти, щодо ринку ветеринарної фармації в ЄС.

\section{Матеріал і методи досліджень}

Наші дослідження базуються на даних розміщених на офіційних інтернет-сторінках: Свропейського агентства з лікарських засобів (ЕМА) і Комітету з лікарських засобів для ветеринарного використання (CVMP), що містять інформацію про законодавче та нормативно-правове забезпечення фармацевтичної промисловості та ринку лікарських засобів, зокрема лікарських засобів для ветеринарії. В роботі використовували методи аналізу та синтезу, індукції та дедукції. Також використані традиційні методи спостереження, контент-аналізу, правової та альтернативної статистики, формалізації та узагальнення.

\section{Результати та їх обговорення}

Фармацевтична промисловість у ЄС працює за високими стандартами щодо управління якістю при розробці, виробництві та контролі лікарських засобів. За даними Бельгійської організації "Animalhealth europe" ЄС є другим найбільшим ринком лікарських засобів для ветеринарії у світі та займає 1/3\% світового ринку 3 конкурентоспроможністю своєї продукції, обіг коштів складає 599 млрд., євро в рік, кількість компаній - 292 одиниць.

Децентралізованим агентством $\mathrm{CC} є$ EMA, що відповідає за наукову оцінку, нагляд і моніторинг безпеки лікарських засобів. Структурним підрозділом
EMA є CVMP, що несе відповідальність за безпеку ветеринарних лікарських засобів на ринку.

Так, для вдосконалення, адаптації до наукового прогресу, динамічності ринку та нестабільності економік - Європейським парламентом та Радою Європейського Союзу від 11 грудня 2018 року прийнято Регламент 2019/6, щодо ветеринарних лікарських засобів на скасування Директиви 2001/82. Цей Регламент прийнятий для зменшення адміністративного навантаження, зміцнення внутрішнього ринку та полегшення виходу на ринок ветеринарних лікарських засобів, при цьому гарантуючи найвищий рівень охорони здоров'я людей, тварин та навколишнього середовища.

В цьому ж Регламенті прописано, про необхідність здійснювати контроль за всім ланцюгом розповсюдження ветеринарних лікарських засобів, тобто від розробки, виробництва до постачання кінцевому споживачеві. Акцентуючи увагу, на тому що ветеринарні лікарські засоби $з$ третіх країн повинні відповідати тим самим вимогам, що застосовуються до ветеринарних лікарських засобів, вироблених в СС, або за вимогами, які визнані щонайменше еквівалентними.

Для прикладу, подано схему законодавчої процедури поетапного проходження Регламенту 2019/6 (проекту) в Свропейському Союзі (СС).

Ветеринарні лікарські засоби, що продаються в межах СC виробляють відповідно 3 "ЕC Rules for Good Manufacturing Practice” - "Свропейськими стандартами належної виробничої практики”.

Належна виробнича практика (GMP) - цілісна система забезпечення якості, орієнтована на чітке дотримання вимог нормативних документів щодо стабільності, належної якості і безпечності від початку переробки сировини до випуску готової продукції. У СС Комісією прийнято дві директиви, що встановлюють принципи та правила GMP:

Директива 2003/94/EC стосується лікарських засобів для людини;

Директива 91/412/EЕC стосується лікарських засобів для застосування у ветеринарії.

Конкретніші вимоги, які узгоджуються з принципами цих директив, викладені в настанові GMP, яку використовують для оцінювання заяв на одержання ліцензій на виробництво та на підставі якої, інспектують виробників лікарських засобів. Тобто, компанія яка виходить на ринок зі своєю продукцією подає до Свропейського агентства з лікарських засобів (Агентство) заявку на отримання ліцензії (реєстраціі), що діє одночасно у всіх країнах-членах ЄС. Ця процедура видачі дозволів (ліцензій) є “централізованою” або “спільною” і обов'язковою для всіх фармацевтичних виробників, незалежно від того, де реалізується продукція - на території СС, чи за його межами. Система ліцензування виробництва (manufacturing authorisations) дає дозвіл на продаж продукції виробникам на Європейському ринку, чия діяльність регулярно інспектується компетентними уповноваженими органами із застосування принципів управління ризиками щодо якості. 


\section{I етап}

Пропозиція проекту цриймаеться Свропейською комісією (СК), доповнюється (за потреби) та передається в Раду Європейського Союзу (РЕС) та Європейський парламент (ЄII)

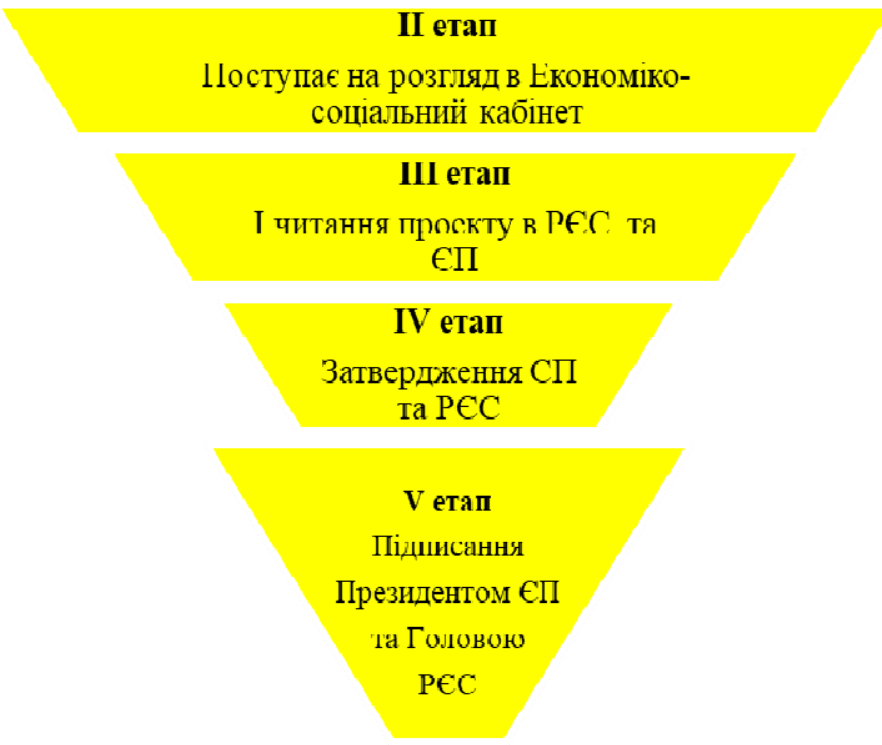

Pис. 1. Схема звичайної законодавчої процедури (COD) в СC

Видача торгових ліцензій (marketing authorisations) передбачає проходження всіма лікарськими засобами експертизи у компетентному уповноваженому органі, щоб гарантувати їхню відповідність сучасним вимогам щодо безпеки, якості та ефективності.

Простіше кажучи, регулювання лікарських засобів у ЄС передбачає прийняття рішення про те, чи можуть нові препарати, розроблені фармацевтичною промисловістю, бути придатними для виведення на ринок, і чи залишаться вони безпечними для використання, коли з'являться на ринку.

Головним завданням Агентства $\epsilon$ те, що рішення про ліцензування виробництва і реєстрацію лікарських засобів базується на об'єктивній, науковій оцінці ï якості, безпеки та ефективності. У випадку підозри про непридатність, щодо певного лікарського ветеринарного засобу, Агентство проводить повторну перевірку через свій Комітет патентних лікарських засобів (CPMP - Committee for Proprietary Medicinal Products).

СРМР інспектує підприємство, від якого була подана заявка на видачу дозволу на продаж у Агентство (згідно 3 централізованою процедурою), та готує рекомендацію, яка потім передається до Європейської комісії що несе остаточну відповідальність за надання, відмову, скасування чи призупинення дозволу на продаж.

Окрім підготовки та видачі ліцензій щодо ветеринарних лікарських засобів Агентство відповідає за:

- надання громадськості відповідної інформації про ветеринарні лікарські засоби та їх регулювання;

- постійний моніторинг та оцінку безпеки ветеринарних лікарських засобів на ринку (відомий як “фармаконагляд”);
- рекомендацію максимальних меж залишків (МДК - максимально допустима концентрація лікарських залишків у продуктах харчування тваринного походження);

- розробку нормативних та наукових рекомендацій для надання допомоги компаніям у всіх сферах, що стосуються розробки та продажу ветеринарних лікарських засобів;

- надання наукових рекомендацій щодо використання антибіотиків, 3 метою мінімізації стійкості до протимікробних препаратів;

- надання наукових рекомендацій 3 питань, переданих до Агентства державами-членами ЄC або Європейською Комісією щодо ветеринарних лікарських засобів (“процедури перенаправлення”).

Проаналізувавши вищевикладене, зрозумілим $є$ те, що створення системи, яка міститиме інформацію щодо ветеринарних лікарських засобів - за показниками ефективності, безпечності $є$ відповідальним завданням в галузі ветеринарної фармації України.

Поточна ситуація на ветеринарному фармацевтичному ринку України, це стимул для реструктуризації галузі, посилення конкурентного середовища та активного переходу на стандарти і вимоги з якості СС. Крім того гармонізація основних вимог національних стандартів 3 вимогами ЄС дасть змогу захистити українського виробника фармацевтичної продукції від конкуренції з низькоякісною продукцією. Підприємства що успішно реструктуризуються і витримають жорстку конкуренцію, зможуть конкурувати і на міжнародних ринках. 


\section{Висновки}

Сьогодні в Україні впроваджується комплексна фармацевтична система якості ветеринарних лікарських засобів, яка захистить споживача від неякісних чи фальсифікованих продуктів.

Впровадження міжнародних стандартів і вимог за якими працюють виробники $\mathrm{CC}$, дасть можливість вітчизняним виробникам ветеринарних лікарських засобів бути конкурентоспроможними серед учасників вітчизняного та міжнародного ринків.

\section{References}

Bushueva, I., Parchenko, V., Shcherbyna, R., Safonov, A., Kaplaijshenko, A., Gutyj, B., \& Hariv, I. (2017). Tryfuzol - New original veterinary drug. Fac. Pharm. Ankara. Ankara Ecz. Fak. Derg., 41(1), 42-49. doi: 10.1501/Eczfak 0000000594.

Bushuieva, I.V. (2013). Marketynhovi doslidzhennia rozvytku rynku veterynarnykh preparativ ta oblasti veterynarnoi farmatsii. Zaporozhskyi medytsynskyi zhurnal, 3, 90-93 (in Ukrainian).
Harvas, H.D., \& Muzyka, P.M. (2017). Klasteryzatsiia vyrobnytstva veterynarnykh preparativ $\mathrm{V}$ umovakh Yevrointehratsii. Naukovyi visnyk Lvivskoho natsionalnoho universytetu veterynarnoi medytsyny ta biotekhnolohii imeni S. Z. Hzhytskoho. Seriia "Ekonomichni nauky". 19(81), 118-122. doi: 10.15421/nvlvet8121 (in Ukrainian).

Kosenko, Iu.M. (2014). Vyrobnytstvo veterynarnykh preparativ za pryntsypamy nalezhnoi vyrobnychoi praktyky. Lviv. NTB Instytutu biolohii tvaryn i DNDKI vetpreparativ ta kormovykh dobavok, 15(4), 233-238 (in Ukrainian).

Velychko, V.O., Hrymak, A.V., \& Senyshyna, T.Ye. (2014). Marketynh, yak efektyvnyi faktor doslidzhen konkurentospro-mozhnosti na rynku produktsii dlia vetmedytsyny. Lviv. NTB Instytutu biolohii tvaryn i DNDKI vetpreparativ ta kormovykh dobavok, 15(2, 3), 320-325 (in Ukrainian).

Zakon Ukrainy "Pro veterynarnu medytsynu". Rezhym dostupu: http://zakon5.rada.gov.ua/laws/show/249812 (in Ukrainian). 